\title{
POSITION
}

\section{TORSTEN RINGBERG}

\section{BEVIDSTGØRELSE SOM ETISK AKTIVITET OG ANTROPOLOGISK METODE}

I 1951 foreslog Sol Tax (1958) at gøre antropologien aktionsorienteret. Han mente, at akademisk epistemologi langt fra er neutral og uengageret, som det ofte er hævdet, men at den altid vil være etnocentrisk og forudindtaget (Tax 1958). Dette forhold er et af antropologiens vanskelige dilemmaer, som man har diskuteret livligt gennem det sidste halve århundrede. Men selv om der er forskel på at være akademiker og aktivist, så behøver det ene ikke at udelukke det andet (se også Fetterman 1983:221). Som en begyndelse til at integrere aktivitet og teoretisering finder jeg Freires (1970) bevidstg $ø$ relsesbegreb og dets anvendelse i sociologisk forskning overordentlig inspirerende. Dette vil jeg diskutere på baggrund af et mindre feltarbejde i Vanuatu, hvor denne artikels forfatter blev involveret i en lokal strid om træfældningskoncessioner.

\section{Skovhugst og gyldne løfter}

På en fire måneders tur til Vanuatu i 1989 blev jeg involveret i en lokal strid mellem et taiwanesisk tømmerfirma, den lokale museumsinspektør og en række indfødte folk. Tømmerfirmaet havde forhandlet sig frem til en aftale på Pentecost, hvori det lovede $\emptyset$ konomisk udvikling, skoler, veje og andre faciliteter til gengæld for ret til ,selektiv fældning " i regnskoven. De lokale overhoveder var positivt indstillede over for projektet og blev støttet af embedsmænd i den nationale NiVanuatu regering, der søgte at bringe nye indtægter til gruppen. Hvad de ikke vidste var, at et andet taiwanesisk tømmerfirma, der havde forhandlet et lignende arrangement med en gruppe indfødte på en af de andre øer to år tidligere, havde ryddet en betragtelig del af den beboede regnskov og efterladt lokalbefolkningen et område med kraftig jorderosion og et meget begrænset grundlag for dens subsistensbrug. Dertil kom, at da de sidste træer var fældet, havde tømmerfirmaet erklæret sig fallit og nægtet at opfylde sine økonomiske og sociale forpligtelser.

Selv hvis det taiwanesiske tømmerfirma skulle vise sig at overholde aftalen, så tydede vort møde med overhovederne på, at de ikke var opmærksomme på en række mulige negative konsekvenser af træfældning såsom den økologiske indvirken, tabte indtægtsmuligheder ved at overgive finbehandlingen af tømret til taiwaneserne, at den kortfristede indtægt fra træfældning ville være utilstrækkelig til at dække de langsigtede udgifter forbundet med drift og vedligeholdelse af skoler og øvrig infrastruktur, og endelig dramatiske samfundsøkonomiske og -politiske ændringer i deres kulturer forårsaget af en ensidig og pludselig overgang til markedsøkonomi. 
For at imødegå den ensidige propaganda fra tømmerfirmaet arrangerede museumsinspektøren et weekendmøde i Port Vila, Vanuatus hovedstad. Dette møde inkluderede repræsentanter fra Ministeriet for Naturresourcer, de lokale overhoveder, og mig. Repræsentanter for tømmerfirmaet var også inviteret, men kom ikke. På mødet var der en udbredt bekymring over, at de berørte folk kun havde hørt tømmerfirmaets side af sagen og enighed om, at de lokale overhoveder måtte præsenteres for en række andre perspektiver.

Museumsinspektøren og repræsentanterne for ministeriet kom med adskillige forslag som for eksempel en såkaldt ,walkabout sawmill“ (en bærbar maskine, der kunne omdanne råt tømmer til forarbejdede træprodukter og derved øge værdien af tømret ganske betragteligt), økoturisme og en begrænsning af den foreslåede selektive træfældning. (Det selektive aspekt af aftalen var i praksis irrelevant, idet den vanskelige adgang til udvalgte træer nødvendiggjorde fældning af den omkringliggende skov). Min rolle blev at producere en videodokumentarfilm, der inkluderede klip, der viste konsekvenserne af træfældning på naboøen, samt andre, der viste varige ødelæggelser forårsaget af totalskovhugst.

Mødet var præget af aktiv diskussion og fortsatte over to fulde dage. Til sidst besluttede de lokale overhoveder, traditionen tro, at tage den ny information med hjem og fortsætte diskussionerne med deres respektive folk. ${ }^{1}$ En uge senere havde mere end halvdelen af dem besluttet at afslå tømmerfirmaets tilbud.

Med mere end halvdelen af området afskåret fra træfældning blev totalhugst (som sandsynligvis var det taiwanesiske firmas hensigt) umuliggjort. Denne ændring i planerne var ikke forudset af tømmerfirmaet, som allerede havde beordret tungt maskinel dirigeret til Vanuatu. Ironisk nok begyndte de store maskiner at ankomme til Port Vila Havn kort efter, at beslutningen om at modstå tømmerfirmaets forslag var truffet. De lokale overhoveder havde på dette tidspunkt endnu ikke skrevet under på noget. Eftersom tømmerfirmaet allerede havde investeret betragtelige beløb i fragt, var de ikke indstillet på at give op så let. De satsede derfor på deres kontakter i regeringen, der var interesseret $\mathrm{i}$ at skabe hurtig kapital til den slunkne statskasse. Tømmerfirmaets præsident ankom til Port Vila for at forsøge at påvirke regeringsmedlemmer i forskellige indflydelsesrige positioner. Desværre for ham forsøgte han at bestikke en embedsmand fra et lokalsamfund, der ifølge museumsinspektøren lægger stor vægt på ærlighed. Dette bragte hele affæren op på højeste politiske niveau, og med udsigt til en intern revision af bestikkelsesskandalen blev det besluttet at fængsle lederen af det taiwanesiske firma. Jeg skal ikke gå yderligere i detaljer, men blot nævne, at den omtalte forretningsmand blev sendt ud af landet.

I stedet for kun at observere involverede jeg mig i ovennævnte lokalanliggende ved at støtte mødet og bidrage til diskussionen. En sådan indblanding vil blive ugleset på mangen et akademisk bjerg, måske især fordi efterfølgende ændringer i lokalkulturernes samfundsstrukturer kunne argumenteres at være forårsaget af antropologen, som derved havde påvirket de empiriske data, der senere indgår som del af en teoretisk samfundsanalyse. Et af argumenterne ville være, at en så direkte indblanding forårsager unaturlige forandringer, som ikke kan henføres til de interne kulturelle modeller, der ønskes klarlagt. Men etisk set var problemet, at havde vi ikke holdt dette møde, kunne resultatet meget vel have været kulturelt folkedrab, ødelagt subsistens og flere ufrivillige lavindkomstarbejdere i hovedstaden.

Denne sag illustrerer diskussionen mellem ,aktivister“ og ,akademiske antropologer.“ Aktivisterne kan med rette stille spørgsmålet, om den akademiske antropologi, etisk set, kan forholde sig passivt til det taiwanesiske firmas mis- (eller manglende) informati- 
on af lokalbefolkningen, mens akademikerne kan påpege, at en indgriben i lokale anliggender ligger uden for deres kompetence, mandat og tilladelse. Jeg skal her argumentere for, at en vis indblanding i lokale anliggender kan være til fordel for både antropologisk teori og etik.

\section{Bevidstgørelse som etisk aktivitet}

Som del af feltarbejdet bør antropologer ${ }^{2}$ tage del i bevidstgørelsen ${ }^{3}$ af de folk, de studerer, og hjælpe den lokale befolkning med at forholde sig til fremtidige og udefrakommende udfordringer til deres samfundsværdier og traditioner. Den filosofiske baggrund herfor er blevet fremlagt af den brasilianske reformist Freires, der blandt andet nævner, at „kun gennem øget bevidstgørelse kan mennesker som vidende subjekter, og ikke blot modtagende individer, udvide deres overvejelser over de socialpolitiske virkeligheder, som skaber deres liv og evne til at forandre disse virkeligheder“ (1970:452). Den underliggende antagelse i bevidstgørelsesbegrebet er, at refleksivitet skaber magt (Ortner 1984:151), og at folk med social magt kan skabe de resultater, de ønsker. I Vanuatu præsenterede vi overhovederne for en række informationer. De valgte en løsning baseret på det udvidede vidensgrundlag, de havde opnået om moderne ,udvikling “ $\mathrm{i}$ almindelighed og tømmerhugst i særdeleshed. Vi hjalp dem med at se, hvordan udefrakommende praksis påvirker deres lokale kulturer og skabte dermed en ændring i deres opfattelse af sig selv og andre (se også Henriksen 1990:120; MayburyLewis 1990:138). Antropologer burde være ideelle kandidater til en sådan tværkulturel kommunikation på grund af vores kulturelle indsigt og praktiske erfaringer. Antropologer bør dog til stadighed tilstræbe ikke at indblande personlige meninger (som for eksempel passivitet er et udtryk for), men i stedet påpege de forskellige sociale udviklingsmæssige muligheder, det samfund, han lever og forsker i, kan vælge imellem, de mulige praktiske konsekvenser af sådanne beslutninger, samt den potentielle integrationsmulighed mellem forskellige muligheder og de eksisterende samfundskulturelle værdier (Cresswell 1968:412). Set ud fra denne synsvinkel minder bevidstgørelsesbegrebet om Bakhtins (1981) „polyfone stemmer“. Bakhtins begreb er værdifuldt, fordi det fremhæver, at virkeligheden har mange realiteter og ikke kan reduceres til ensartede, monologisk autoritative forklaringer (Graves and Shield 1991:148). Som repræsentant for den vestlige verden kan antropologer ikke tillade sig at lade som om, vi ikke kender til den ,,byrde det er at blive civiliseret“, som vi til stadighed påtvinger de indfødte samfund (Baer i Hastrup \& Elsass 1990:306,308). Jeg foreslår at indføje bevidstgørelsesbegrebet i den antropologiske etiske kode, fordi det vil bibringe den akademiske antropolog institutionel støtte til at informere indfødte folk om udefrakommende socialpolitiske virkeligheder, i hvad form (politisk, økonomisk, ideologisk), de nu måtte forekomme. ${ }^{4}$ Dette vil med Tax's ord sikre en præsentation af ,oprigtige“" alternativer, mellem hvilke de indfødte kan vælge (1975:516), som I Vanuatu, hvor vi fokuserede på at tydeliggøre konsekvenserne af træfældningen for kulturel overlevelse og alternative valgmuligheder. Det er naturlivis vigtigt, at antropologen inddrager andre specialister, der kan forholde sig til de økologiske, økonomiske, sociale og politiske konsekvenser. ${ }^{5}$ Antropologers tilstedeværelse er vigtig, idet de kan ,oversætte“ specialistviden til brugbar lokalviden. COICAkonferencen ${ }^{6}$ i 1988 viste, hvordan en øget grad af bevidstgørelse hjalp amazonindianerne til at organisere sig og blive respekteret som part- 
nere på lige fod med fredningsfolk, forretningsfolk og regeringsmedlemmer ved forhandlinger om Amazonas' og deres egen fremtid. En hyppig kritik af indfødt ret til selvbestemmelse er, at vi er part af et globalt samfund, hvor individuelle nationers beslutning berører os alle. Dette argument er også benyttet af naturfredningsorganisationer imod indfødte folk, der som led i deres ændrede levevis er begyndt at tage økologisk kortsigtede beslutninger (Redford \& Stearman 1993; Sponsel 1992b; Edgerton 1992; Kirch 1982). Som argument herimod er det blevet fremhævet, at mens indfødte folks brug af naturressourcer kan true dyrearter og miljø, så er udstrækningen af denne praksis næppe sammenlignelig med graden af ødelæggelse forårsaget af den industrielle verden (Sponsel 1992b). Kritikken af indfødte folk har haft tilbøjelighed til at bebrejde offeret i stedet for forbryderen. I sidste ende fornægter den indfødte folks medfødte ret til selv at vælge.

Bevidstgørelsesbegrebet kan spille en positiv rolle i denne debat og integrere ,menneskelighed og videnskabelig orientering“ (cf. Herskovits i Hatch 1983:101) og dermed sikre en gensidig udveksling af viden - det, Habermas betragter som det højeste mål inden for videnskaben (i Scholte 1972:452).

\section{Bevidstgørelse som metode}

En antropologs aktive engagement behøver ikke nødvendigvis at sætte dennes forskning på spil. Faktisk kan antropologen skabe situationer, der er interessante fra et rent teoretisk perspektiv. Ifølge Scholte (1972:447) vil en udvidelse af de indfødte folks bevidsthed om udefrakommende sociale og kulturelle realiteter højst sandsynligt skabe observerbare reaktioner. Disse reaktioner åbner et vindue, gennem hvilket antropologen kan observere, hvordan beslutningsprocesser skabes, såvel som hvordan traditioner ændres strukturelt, og nye indarbejdes.

I Vanuatu herskede der uenighed folk imellem både før og efter overhovedernes møde i Port Vila. Et par af lederne nævnte ved vores møde, at de ville ændre deres holdning fra at være imod tømmerfirmaet til en betinget positiv holdning, hvis de kunne få del i træfældnings- og bearbejdningsprocessen. Desværre var tømmerfirmaets repræsentant, som tidligere nævnt, ikke til stede til at diskutere denne mulighed. Flertallet af overhovederne besluttede dog under alle omstændigheder at ændre deres oprindelige positive holdning til en afvisning af tømmerfirmaets ,tilbud“. En analyse af, hvordan disse ændringer skete gennem en omprioritering af sociokulturelle modeller, synliggjorde dybereliggende strukturer. De sociokulturelle modeller, der blev benyttet af de indfødte (og af os) til at skabe en forståelse, ændrede karakter efterhånden som ny information blev bearbejdet, idet refleksivitet skaber en selektiv forholden sig til eksisterende normer, pålægger den sociale oplevelse en ny orden og gør det socialt usynlige synligt ved at reformulere forholdet mellem modtagerne og deres sociokulturelle omgivelser (Vickers i Harries-Jones 1990:233ff). Det er denne proces, antropologen kan følge i praksis, og som kan give et værdifuldt indblik i virkelighedskonstruktion. Det kom således til udtryk under Port Vilamødet, at for visse af overhovederne var det den prestige, der var forbundet med vejanlæg og bygninger, snarere end det var disses praktiske nytte, der var afgørende for deres positive holdning. Denne traditionelle fokusering på prestige ændredes efter, at de erkendte, at denne måde at se verden på (dvs. deres kulturelle modeller) ikke duede til at forstå tømmerfirmaets aktiviteter, der blev en trussel mod deres kulturelle overlevelse. ${ }^{7}$ 
Bevidstgørelsesprocessen skaber en forholden sig til ens egen logiske begrundelse og kulturmodeller. Antropologen kan derved hjælpe lokalbefolkningen til at transformere kulturens kapacitet fra ubevidst reproduktion til en styring af kulturel selvproduktion, som det var tilfældet i Vanuatu. Fra et teoretisk synspunkt er denne holdning baseret på praksisteorierne, hvor selvreflekterende individer ses som ansvarlige for ændringer i de kulturelle strukturer. Det gælder for eksempel for både Giddens' „diskursive bevidsthedsbegreb“ (1984:7) og Shweders „hensigtrettede menneskebegreb“ (1991:97), der begge ser individet som en potentiel faktor i strukturelle ændringer - forudsat en bevidstgørelse sker. Dette følger Sahlins, der har peget på, at det netop er ,,sammenstødet mellem kulturelle forståelser og interesser, der gør forandringer og reproduktion klart synlige“ (1981:72). Det er disse sammenstød, vi bevidst kan søge at skabe, for derved at åbne en mulighed for erkendelse og ændring. Indblanding tillader os at observere både mikroprocessuelle konsekvenser (hvordan introduktion af ny praksis påvirker den enkeltes bevidstgørelse) og makroprocessuelle konsekvenser (hvordan bevidstgjorte aktører påvirker kulturelle traditioner; Ortner 1984:19). Ændringer er interessante fra et teoretisk perspektiv og synliggøres ved antropologens introducering af nye begrebsverdener.

Ovennævnte betragtninger skal ikke fortolkes som en anbefaling af, at man bør initiere samfundsforandringer, for at akademikere kan få noget at studere. Det er derimod en understregning af det mulige interessesammenfald mellem det at være aktivist af etiske grunde og det at være forsker af akademiske grunde. Bevidstgørelsesbegrebet skal heller ikke ses som en nedvurdering af de indfødtes evne til at forstå metakulturelle indflydelser. Men realiteten er, at de færreste kulturer har en sådan forståelse samt erfaring med at takle hurtige, radikale og uhørt stærke sociokulturelle processer (Bilmes 1985:135). Derfor vil en øget viden om den ,ydre verden“ hjælpe indfødte folk til at forstå og modstå de drastiske sociokulturelle indflydelser udefra. Dertil kommer ifølge Caulfield $(1972: 189,194)$, at en $\varnothing$ get grad af bevidstgørelse om egne og andres skikke medvirker til en stærkere følelse af kulturel identitet.

\section{Ansvarlig antropologi}

Antropologi er en akademisk disciplin, der i udstrakt grad lever af mødet med indfødte folk. Ikke desto mindre giver dette møde ofte ringe udbytte for de indfødte og risikerer endog at stille dem ringere. Forskeres frygt for at blive involveret uden for strikse akademiske grænser - måske især en amerikansk antropologisk bekymring - er muligvis et resultat af overdreven selvopfattelse og overfølsomhed over for andre folks kulturelle og politiske integritet, eller muligvis er det, fordi vi distancerer os fra virkeligheden, følger det akademiske krav om neutralitet og lukker os inde i en universitetverden - det, Harries-Jones kalder „,neddæmpningssyndromet“ (1990:221,230).

Med et ubeskriveligt pres på deres politiske, økonomiske, kulturelle og økologiske ressourcer behøver de fleste indfødte folk betydelig mere støtte end den, bevidstgørelsesbegrebet kan yde. Ikke desto mindre er en aktiv bevidstgørelse af en lokalbefolkning et skridt i retning af en mere ansvarlig akademisk antropologi, der sikrer en refleksiv dialog med de indfødte, virker som en buffer mod vestlig etnocentrificering af den fjerde verden og formindsker de værste eksempler på videnskabligt metasprog med dets asymmetriske udveksling af information (Sponsel 1992a:299), hvor der tales om de andre, men aldrig 
til de andre (McGrane i Sponsel 1992a:229). Hvis bevidstgørelsesbegrebet samtidig kan føre til ny viden og justering af eksisterende samfundsteorier, som argumenteret ovenfor, så er både aktivisternes krav om en etisk holdning og de akademiske antropologers krav om teoretisk relevans opfyldt.

Hvorvidt akademisk antropologi er indstillet på at inkludere bevidstgørelsesbegrebet i de etiske forskrifter og dermed støtte i stedet for at fordømme en ansvarlig antropologi, kan der kun gisnes om. Men hvis den akademiske antropologi forbliver passiv tilskuer til den strukturelle udbytning af de indfødte folk, så kan der med al mulig grund stilles spørgsmålstegn ved antropologiens etiske mandat.

Torsten Ringberg

1. Alle lederne fik en kopi af videoen, som de kunne vise hjemme på deres lokale VCR. De fleste af lokalsamfundene deltog i et omfattende projekt iværksat af museumsinspektøren, hvor de dokumenterede deres egne traditioner på film. De var således vant til filmmediet, men ikke til fjersyn som sådan.

2. Indlæggets fokus er akademiske antropologer, der står over for etiske dilemmaer, når de forsøger at følge det Amerikanske Antropologiske Selskabs etiske forskrifter. Diskussionen omfatter således ikke de antropologer, der er ansat i mere anvendtorienterede stillinger uden for den akademiske verden, idet der allerede eksisterer separate etiske forskrifter for sådant arbejde (se appendix A, F og H i Fluerh-Lobban; 1991:239, 263, 270). For et generelt overblik over de mange problemstillinger, der har været diskuteret gennem de sidste tredive år, henvises til (i tillæg til allerede nævnte forfattere) Berreman 1968; Gjessing1968; Holmberg 1971; Adams 1975; Scholte 1976; Punch 1986; Bodley 1988, 1990; Appell 1992; Johannsen 1992; se ogsaa Paine (red.) 1990 samt Hamnett et al. 1984 for en historisk kritisk gennemgang.

3. I sagens natur er begrebet tiltænkt primært selvbestemmende, velfungerende og kulturelt integrerede folk, hvis behov i højere grad er information og erkendelse af de ydre sociale trusler og muligheder. Ikke desto mindre er det selvfølgelig bydende nødvendigt, at antropologer, der måtte være vidne til genocid, etnocid, $ø$ kocid eller lingocid overbringer information herom til græsrodsbevægelser og internationale instanser.

4. I Cassell and Jacobs 1987 foreslås det, at de normative etiske forskrifter bor baseres på lokale problemer såsom børnedrab, mishandling af ældre, vold i hjemmet, konflikter osv. Mangfoldigheden af etiske problemer gør et sådant forsøg illusorisk. Ikke desto mindre findes der et antal forsøg på dette (f.eks. Gilbert et al. 1991:210; Mitchell 1983; Pierce 1971:346). Løsningen af konkrete problemer må afhænge af den enkelte antropologs betænksomhed og forståelse, idet ,hver begivenhed er en del af en labyrint af overvejelser og forpligtelser" (Fetterman 1983:221). Reference til etiske forskrifter henviser derfor her til disse som normative, som en generel struktur, inden for hvilken antropologen har en række personlige valg.

5. Havde det for eksempel været en naturfredningsorganisation, der havde foreslået de indfødte, at deres område skulle bevares som beskyttet park, ville det have været lige så vigtigt for antropologen, at befolkningen blev informeret om de mulige positive og negative konsekvenser heraf, såsom tab af økonomisk potentiale, fastlåsning af deres måde at bruge naturen på, mulighed for turistindtægter og beskyttelse af kontrol med kulturelle og symbolske værdier.

6. COICA står for „Coordinadora de las Organizaciones Indigenas de la Cuenca Amazonica“ og repræsenterer 229 af Amazonas' indianergrupper med i alt 1,2 millioner medlemmer i Peru, Bolivia, Ecuador, Brasilien og Colombia. COICA-mødet resulterede i dokumentet „Two Agendas on Amazon Development“, som blev publiceret i Cultural Survival Quarterly 1989 og i uddrag af Redford \& Stearman 1993.

7. En måned efter den første kontakt med de indfødte folk erfarede jeg, at et af folkene havde brugt alle de penge, de havde sparet op fra turisme og handel, på en lastbil. At lastbilen ikke kunne køre var mindre betydningsfyldt. Jeg nævnte det for museumsinspektøren, som forklarede, at lastbilen var et statussymbol mere end noget andet. Denne historie viser måske styrken af lokale traditioner, og hvordan vestlige produkter ikke nødvendigvis skaber dramatiske ændringer i sig selv, men kan indarbejdes i eksisterende symbolske meningssystemer. 


\section{Litteratur}

Adams, Richard N.

1975 Current Anthropology 16(4).

Appell, George N.

1992 Reviews in Anthropology 21.

Bakhtin, M. M.

1981 The dialogic imagination. Austin: University of Texas Press.

Berreman, Gerald D.

1968 Is Anthropology Alive? Social Responsibility in Social Anthropology. Current Anthropology 9(5).

Bilmes, Jack

1985 Freedom and Regulation. An Anthropological Critique of Free Market Ideology. Research in Law and Economics 7.

Bodley, John H. (ed.)

1988 Tribal Peoples and Development Issues. A Global Overview. Mountain View: Mayfield Publishing Company.

1990 Victims of Progress, 3. udg. Mountain View: Mayfield Publishing Company.

Cassell, Joan \& Jacobs, Sue-Ellen (eds.)

1987 Handbook on ethical issues in anthropology. Special Publication of the American

Anthropological Association, No.23. Washington, D.C.

Caulfield, Mina

1972 Culture and Imperialism: Proposing a New Dialectic. I: Del Hymes (ed.): Reinventing Culture. Pantheon.

Cresswell, Robert

1968 Reply to Social Responsibilities Symposium by Berreman, Gjessing, and Gough. Current Anthropology 9(5).

Edgerton, Robert B.

1992 Sick Societies: Challenging the Myth of Primitive Harmony. New York: The Free Press

Fetterman, David M.

1983 Guilty Knowledge, Dirty Hands, and Other Ethical Dilemmas: The Hazard of Contract Research. Human Organization 42(3).

Fluehr-Lobban, Carolyn (ed.)

$1991 \quad$ Ethics and the Profession of Anthropology. Dialogue for a New Era. University of Pennsylvania Press.

Freire, Paul

1970 The Adult Literacy Process as Cultural Action for Freedom. Harvard Educational Review $40(2)$.

Giddens, Anthony

1984 The Constitution of Society: Outline of the Theory of Structuration. Glasgow: Bell and Bain Ltd.

Gilbert, M. Jean, Nathaniel Tashima \& Claudia C. Fishman

1991 Practicing Anthropologists' Dialogue. Ethics and the Profession of Anthropology. I: Carolyn Fluehr-Lobban 1991.

Gjessing, Gutorm

1968 The Social Responsibility of the Social Scientist, Current Anthropology 9(5). 
Graves, William \& Shield, Mark A.

$1991 \quad$ Rethinking Moral Responsibility. I: Fluehr-Lobban 1991.

Hamnett, Michael P., Douglas J. Porter, Amarjit Singh, Krishna Kumar

1984 Ethics, Politics, and International Social Research: From Critique to Praxis.

Harries-Jones, Peter

1990 From Cultural Translator to Advocate: Changing Circles of Interpretation. I: Robert Paine 1990.

Hastrup, Kirsten \& Peter Elsass,

1990 Anthropological Advocacy: A Contradiction in Terms? Current Anthropology 31(3).

Hatch, Elvin

$1983 \quad$ Culture and Morality. New York: Columbia University Press.

Henriksen, Georg

$1990 \quad$ Anthropologists as Advocates: Promoters of Pluralism or Makers of Clients? I: Robert Paine 1990.

Holmberg, Allan R.

1971 Experimental intervention in the field. I: Doughty Dobyns and Lasswell (eds.): Peasants, Power, and Applied Social Change: Vicos as a Model. Beverly Hills: SAGE Publications.

Johannsen, Agneta M.

1992 Applied Anthropology and Post-Modernist Ethnography. Human Organization 51(1).

Kirck, Patrick V

1982 The Impact of the Prehistoric Polynesians on the Hawaiian Ecosystem. I: Pacific Science 36(1).

Maybury-Lewis, David

1990 A Special Sort of Pleading: Anthropology at the Service of Ethnic Groups. I: Robert Paine 1990.

Mitchell, J,C

$1983 \quad$ Case and situation analysis. Sociological Review 31(2).

Ortner, Sherry B.

1984 Theory in Anthropology since the Sixties. Comparative Studies in Society and History 26 (1).

Paine, Robert (ed.)

1990 (1985) Advocacy and Anthropology (2. udg.). Institute of Social and Economic Research. Memorial University of Newfoundland.

Pierce, Joe E.

1971 Reply to Jorgensen. Current Anthropology 12(3).

Punch, Maurice

1986 The Politics and Ethics of Fieldwork. Qualitative Research Methods Series 3. London: Sage Publications.

Redford, Kent H. \& Allyn Maclean Stearman

1992 Forest-Dwelling Native Amazonians and the Conservation of Biodiversity: Interest in

Common or in Collision? Conservation Biology 7(2).

Sahlins, Marshal

1976 Reply to Chilungu. Issues in the Ethics of Research Method: An Interpretation of the AngloAmerican Perspective. Current Anthropology 17(3).

Sponsel, Leslie

1992a Information Asymmetry and the Democratization of Anthropology. Commentary in Human Organization 51(3). 
1992b Myth of Ecology and Ecology of Myths: Were Indigenes Noble Conservationists or Savage Destroyers of Nature? I: Conference Proceedings from The Second Annual Conference on Issues of Culture and Communication in the Asia/Pacific Region, East-West Center Aug 31Sept 4, 1992.

Tax, Sol

1975 [1958] Action Anthropology. Current Anthropology 16(4). 
